Original research article

\title{
The incidence of complications in comatose patients
}

\author{
Mária Šupínová *, Martina Ostrolucká \\ Slovak Medical University in Bratislava, Faculty of Health in Banská Bystrica, Banská Bystrica, Slovak Republic
}

\begin{abstract}
Introduction: Coma is a severe state from which the patient may not awaken for weeks, months or years. Design: A prospective qualitative study based on structured observation.

Objective: The main objective of the study was to identify the incidence of complications in comatose patients.

Sample: A total of 22 respondents in a comatose state with an average age of 54.05 years and an average duration of coma of 3.73 years were included in the study.

Methods: The structured observation method was used to carry out the research. Interval coding of predefined categories of complications was used, with an interval of every 30 days within one year.

Results: A closer relationship between the respondents' sex and the incidence of complications was demonstrated ( $p=0.05)$; conjunctivitis $(p=-0.46)$; inflammation around two-way catheter $(p=-0.57)$; pneumonia $(p=-0.53)$; intertrigo $(p=-0.44)$ and decubitus $(p=-0.48)$. A statistical association between respondents' BMI and the incidence of diarrhea $(p=-0.55)$ and BMI/constipation $(p=-0.78)$ was proven throughout the sample. Significance was not proven between the incidence of complications and respondents' age, not even in relation to the duration of comatose state.

Conclusions: The results of the research have proven that the incidence of the complications monitored in the sample of comatose patients is neither independent of their age nor duration of the comatose state. A closer relationship between the respondents' sex and the incidence of certain complications was demonstrated. Identifying the complications of this condition and the specificities of very demanding nursing care can be beneficial in providing quality nursing care for comatose patients.
\end{abstract}

Keywords: Comatose patient; Comatose state; Complications; Nursing care

\section{Introduction}

The consequences of persistent brain damage remain a major health and social problem.

According to Škutchanová and Minárik (2014), approaches to the long-term consequences of acute brain damage have changed in the history of intensive medicine, from the point of view of nomenclature, diagnosis, prognosis and approach to patients. According to the authors, the result is a colourful mix of opinions and nomenclature that have become unclear.

In 1972, Jennett and Plum described the clinical criteria for Vegetative State (VS) (Škutchanová a Minárik, 2014). They adopted the term "vegetative" from the Oxford English Dictionary, which describes it as "to live a merely physical life". In this state, the organism is capable of growth and development, but it lacks the ability to produce thoughts and feelings (Doležil and Carbolová, 2007). Nowadays, vegetative state is a recognized term, however, according to Škutchanová and Minárik (2014), it is being reconsidered and does not seem to be definitive. Persistent Vegetative State (PVS) can hardly be distinguished from the state of minimal consciousness. The risk of misdiagnosis is high and is estimated to be
37-43\% (Bender et al., 2015). On the contrary, the PVS is easily distinguished from brain death. PVS exists if the state has persisted without improvement for more than 3 months since the onset of the non-traumatic brain injury that had arisen, for example, after global cerebral hypoxia, or 12 months and more since the onset of traumatic brain injury (Doležil and Carbolová, 2007).

The term Apallic syndrome is used in Central European countries, but it is not considered to be adequate in Anglo-Saxon literature. The Anglo-Saxon literature considers the term "vegetative state" to be a satisfactory term. Latin-French terminology adopted the term "coma vigile" (Drábková, 2001). Brain damage of various aetiologies can lead to various disorders of consciousness, which vary from the coma, the vegetative stage, to the state of minimal consciousness. Each condition is characterized by varying degrees of alertness, awareness and pain sensitivity, and requires a different approach with regard to treatment, nursing care and ethical aspects. Its correct identification is therefore crucial in designing or modulating appropriate treatment strategies (Bonsignore et al., 2014). According to Stevens and Bhardwaj (2006), coma is an urgent condition and may be a diagnostic and therapeutic challenge for intensive care.

\footnotetext{
* Author for correspondence: Mária Šupínová, Slovak Medical University in Bratislava, Faculty of Health in Banská Bystrica, Sládkovičova 21, 97405 Banská Bystrica, Slovak Republic; e-mail: maria.supinova@szu.sk http://doi.org/10.32725/kont.2019.023 
Generally, medical and nursing care is provided to patients with brain damage in the department of anaesthesia and intensive care, where the patients manage the acute phase, stabilize and are out of danger of death. With spontaneous breathing, without the need for artificial lung ventilation, patients are transferred to another specialized department or to nursing home care. Whether comatose patients are in a home environment where they are provided with care from family members or in healthcare or social facilities, care is very physically and psychologically demanding and costly. Caregivers must be fully able to deal with the extraordinary stresses associated with the patient's diagnosis (Haškovcová, 2007). Also, according to Puggina et al. (2012), care for patients with severe brain injury poses a social, economic and ethical dilemma, as well as a real challenge for medical staff, as it requires specific expertise.

It follows from the research results by Estraneo et al. (2018) that medical complications are very common in patients with long-term impaired consciousness over a period of at least 6 months after brain damage, regardless of clinical diagnosis, aetiology and age. During the 6 months after the injury, at least 1 medical complication occurred in 188 out of 194 patients (>95\%) and 142 (73\%) experienced at least one serious complication. The most common complications were respiratory, musculoskeletal and cutaneous, followed by endocrine-metabolic abnormalities. The incidence and severity of medical complications in comatose patients require a long-term adequate level of care after the post-acute phase (Estraneo et al., 2018). The risk of morbidity and mortality in comatose patients on artificial pulmonary ventilation in relation to the occurrence of pneumonia and their prevention was covered by Álvarez-Lerma et al. (2018).

The occurrence of decubitis as a complication in palatable patients is also noted by Dincer et al. (2018). The study's authors consider the presence of chronic diseases and immobility as the most significant negative factor.

According to Burns and McLaren (2008), central venous catheters are an indispensable component of critical care, allowing invasive monitoring, facilitating atrial stimulation and renal substitution therapy, and allowing the administration of parenteral nutrition and drugs. However, they are also associated with serious complications, including infection and thrombosis.

In critically ill patients, ocular surface disorders often occur, especially when they are sedentary and immobile, according to experts (Imanaka et al., 1997; Sorce et al., 2009). Corneal and conjunctival abnormalities occur in connection with neurological diseases, coma, infection and mechanical ventilation.

Although it may seem that a coma patient only needs to satisfy biological needs, it is also important to think of spiritual, social and cultural needs. The patient is always considered from a holistic point of view as a holistic being. Chlan et al. (2018), for example, described the positive effect of music therapy on reducing the anxiety of critically ill patients on artificial lung ventilation.

The basic nursing care of the patient in a comatose state includes:

- Nutrition, high quality diet and adequate fluid intake followed by nasogastric intubation, percutaneous endoscopic gastrostomy (PEG) including prevention of aspiration, but also fluid balance and patient weight monitoring.

- Care for adequate emptying and diuresis, care for permanent urinary catheter.
- Provision of basic hygienic care, care for skin and locomotive apparatus: prevention of decubitus, regular positioning, rehabilitation, massage, frequent positioning.

- Monitoring of physiological functions.

- Respiratory care, including: airway patency, care for endotracheal tube, later two-way catheter, mucous membrane humidification and the right airway toilet is important.

- Care for artificial lung ventilation or weaning - disconnection from the ventilator.

- Cavity and mucosal care: oral cavity, eyes, ears, nose.

- Drug administration according to doctor's instructions.

- Sterile treatment of invasive entries.

- Monitoring of patient's manifestations of pain and pain relief (Opavská, 2001; Puggina et al., 2012).

Basal stimulation is used in the care of comatose patients. The use of basal stimulation is very important in terms of the interaction between the patient/client and the nurse (Friedlová, 2008).

The main objective of the study was to identify the incidence of complications in comatose patients and the relationships between the observed variables.

The partial objectives of the study were to:

1. Determine whether the incidence of complications in comatose patients is related to the patients' age.

2. Determine whether the incidence of complications in comatose patients is related to the patients' sex.

3. Determine whether the incidence of complications in comatose patients is related to the duration of the comatose state.

\section{Materials and methods}

\section{The sample}

The selection of respondents was deliberate and targeted. The research group included coma patients hospitalized at Zelený sen, s. r. o., in Banska Bystrica, at the Department of Longterm Intensive Care (JDIS). A total of 22 respondents with the same or similar diagnosis were included in the sample. The group of respondents included patients irrespective of gender, age and social status. The only criterion for inclusion in the study was a comatose state of the patient lasting longer than 6 months, with no differentiation in the degree of alertness or the cause of the comatose condition. For this research, we will use the term comatose patients. We do not consider the size of the sample to be low because of the specificity and low incidence of the comatose patients. It may, however, be a pilot project for more extensive studies into this field.

\section{Research method}

The research method used was a structured observation, which was carried out during nursing care. Interval coding was used with an interval of every 30 days within one year.

The occurrence of pre-determined complications was observed in individual comatose patients, which may be related to long-term comatose state: TS - tracheostomy; KO - conjunctivitis; ST - stomatitis; TSK - inflammation around twoway catheter; PN - pneumonia; ZV - vomiting; HN - diarrhea; ZA - constipation; TF - thrombophlebitis; kNM - bladder bleeding; iNM - bladder infection, ZP - intertrigo; DE - decubitus; ZPEG - inflammation around PEG. Each complication was recorded as newly incurred. As a nutrition assessment 
parameter, we have chosen the BMI index - an objectively observable parameter by a nurse. Biochemical levels of protein levels are considered rather as a parameter monitored and evaluated by the doctor.

The assessment of the presence of the observed complications was every 30 days/once a month, from January 2016 (inclusive) to December 2016 (inclusive). In total, 12 measurements (scale $0-12$ ). The observation was carried out by a nurse who had completed a first or second degree in higher education. Symptoms of individual complications were objectively observable, and each was given medical intervention. The categories observed were of a low degree of deduction. There was no risk of subjective distortion of the acquired knowledge.

The incidence of individual categories of the complications in the reference period was recorded using a scale; 0 - the symptoms of the observed complication are absent; 1 - the symptoms of the observed complication are present.

The variables were defined as the number of observations, out of 12 observations during the year in which a phenomenon was present.

Statistical methods were used to analyze the data obtained; absolute frequency; relative frequency; median; minimum and maximum values; lower and upper quartile; Spearman's correlation coefficient at significance level $p=0.05$. Tables and graphs were used to interpret the results. The reservation is incomplete homogeneity of the sample regarding the depth of perception, and the advantage is the identical environmental conditions of the entire sample as well as the quality and extent of the provided medical and nursing care.

\section{Results}

A total of 22 respondents were included in the sample 12 men (54.55\%) and 10 women (45.45\%). The average age of respondents was 54.05 years. The youngest of the respondents was 32 years old, the oldest 86 years. The average coma duration was 3.73 years. The minimum coma duration was 1 year, maximum 8 years. The body mass index (BMI) was assessed as one of the nutrition indicators. The average values reached 26.75 points, the minimum was 17.3 points and the maximum 32 points (Table 1 ).

Table 1. Distribution of respondents by age and duration of coma

\begin{tabular}{lrrrrrrrr} 
& $n$ & $d$ & SD & Med. & Min. & Max. & $d Q$ & \multicolumn{1}{c}{$h Q$} \\
\hline Age & 22 & 54.05 & 14.03 & 54.0 & 32.0 & 86.0 & 43.0 & 65.0 \\
Duration of coma & 22 & 3.73 & 2.03 & 4.0 & 1.0 & 8.0 & 2.0 & 5.0 \\
BMI & 22 & 26.75 & 4.09 & 27.4 & 17.3 & 32.0 & 23.7 & 29.4 \\
\hline
\end{tabular}

Table 2 summarizes the incidence of complications in the respondents' sample. The most common was tracheostomy, however, it is not considered a complication. It is implemented as a method of ensuring air supply to the lungs. Its mean incidence was 10.55 months, with a minimum occurrence of 1 month and a maximum of 12 months.

The mean incidence of decubitis was (3.86), constipation (3.50), conjuctivitis (2.73), inflammation around two-way catheter (2.45), stomatitis (2.27). This is followed by diarrhea (2.05), intertrigo (2.0), vomiting (1.86), pneumonia (1.09), inflammation in the vicinity of PEG (1.05), bladder infection (0.73), bladder bleeding (0.59) and thrombophlebitis (0.45). Overall, the incidence of complications in the monitored patients is low, indicating a high level of medical and nursing care.

Table 2. Overview of the incidence of complications in the sample (in months)

\begin{tabular}{|c|c|c|c|c|c|c|c|c|c|}
\hline & $n$ & $d$ & SD & Med. & Min. & Max. & $d Q$ & $h Q$ & Range \\
\hline TS & 22 & 10.55 & 3.19 & 12.0 & 1.0 & 12.0 & 11.0 & 12.0 & $0-12$ \\
\hline KO & 22 & 2.73 & 2.90 & 2.0 & 0.0 & 12.0 & 1.0 & 4.0 & $0-12$ \\
\hline ST & 22 & 2.27 & 2.73 & 1.5 & 0.0 & 9.0 & 0.0 & 3.0 & $0-12$ \\
\hline TSK & 22 & 2.45 & 2.22 & 2.0 & 0.0 & 10.0 & 1.0 & 3.0 & $0-12$ \\
\hline PN & 22 & 1.09 & 1.23 & 1.0 & 0.0 & 4.0 & 0.0 & 2.0 & $0-12$ \\
\hline $\mathrm{ZV}$ & 22 & 1.86 & 2.42 & 0.5 & 0.0 & 8.0 & 0.0 & 3.0 & $0-12$ \\
\hline $\mathrm{HN}$ & 22 & 2.05 & 3.00 & 0.0 & 0.0 & 12.0 & 0.0 & 4.0 & $0-12$ \\
\hline $\mathrm{ZA}$ & 22 & 3.50 & 4.25 & 2.5 & 0.0 & 12.0 & 0.0 & 5.0 & $0-12$ \\
\hline $\mathrm{TF}$ & 22 & 0.45 & 1.01 & 0.0 & 0.0 & 4.0 & 0.0 & 0.0 & $0-12$ \\
\hline kMM & 22 & 0.59 & 1.01 & 0.0 & 0.0 & 3.0 & 0.0 & 1.0 & $0-12$ \\
\hline iMM & 22 & 0.73 & 0.83 & 1.0 & 0.0 & 3.0 & 0.0 & 1.0 & $0-12$ \\
\hline $\mathrm{ZP}$ & 22 & 2.00 & 1.48 & 2.0 & 0.0 & 5.0 & 1.0 & 3.0 & $0-12$ \\
\hline $\mathrm{DE}$ & 22 & 3.86 & 5.19 & 0.0 & 0.0 & 12.0 & 0.0 & 11.0 & $0-12$ \\
\hline ZPEG & 22 & 1.05 & 1.40 & 0.5 & 0.0 & 5.0 & 0.0 & 2.0 & $0-12$ \\
\hline
\end{tabular}

Legend: TS, tracheostomy; KO, conjunctivitis; ST, stomatitis; TSK, inflammation around two-way catheter; PN, pneumonia; ZV, vomiting; HN, diarrhea; ZA, constipation; TF, thrombophlebitis; kNM, bladder bleeding; iNM, bladder infection, ZP, intertrigo; DE, decubitus; ZPEG, inflammation around PEG 
The dependence between the different categories of complications was evaluated by the Spearman's correlation coefficient at the significance level $p=0.05$. Closer dependence was demonstrated between the sex of respondents and the incidence of conjunctivitis ( $p=-0.46)$, between sex and inflammation around two-way catheter $(p=-0.57)$, between sex and the incidence of pneumonia $(p=-0.53)$ between sex and the incidence of intertrigo $(p=-0.44)$ and between the incidence of decubitus and respondents' sex $(p=-0.48)$ (Charts $1-5)$. A dependence was also demonstrated between respondents' BMI and the incidence of diarrhea $(p=-0.55)$ and constipation $(p=-0.78)$ (Table 3).

Table 3. Overview of correlations - Spearman's correlation coefficient $r(S)$

\begin{tabular}{|c|c|c|c|c|}
\hline & $\operatorname{Sex} r(S)$ & Age $r(S)$ & Duration of coma $r(S)$ & $\mathrm{BMI} r(S)$ \\
\hline Sex & & -0.12 & -0.04 & 0.23 \\
\hline Age & -0.12 & & -0.06 & 0.12 \\
\hline Duration of coma & -0.04 & -0.06 & & 0.06 \\
\hline BMI & 0.23 & 0.12 & 0.06 & \\
\hline Tracheostomy & 0.03 & 0.27 & 0.15 & -0.35 \\
\hline Conjunctivitis & -0.46 & -0.19 & 0.22 & -0.16 \\
\hline Stomatitis & -0.27 & 0.01 & -0.17 & 0.29 \\
\hline Inflammation around two-way catheter & -0.57 & 0.09 & 0.02 & -0.02 \\
\hline Pneumonia & -0.53 & 0.06 & -0.12 & 0.19 \\
\hline Vomiting & 0.31 & 0.30 & -0.12 & 0.20 \\
\hline Diarrhea & -0.13 & 0.30 & 0.03 & -0.55 \\
\hline Constipation & 0.00 & 0.03 & 0.04 & -0.78 \\
\hline Thrombophlebitis & -0.40 & 0.15 & 0.08 & -0.01 \\
\hline Bladder bleeding & -0.34 & 0.07 & -0.13 & 0.10 \\
\hline Bladder infection & -0.15 & -0.19 & 0.02 & -0.13 \\
\hline Intertrigo & -0.44 & 0.12 & -0.06 & -0.30 \\
\hline Decubitus & -0.48 & 0.22 & -0.37 & -0.23 \\
\hline PEG & -0.13 & -0.06 & -0.05 & 0.27 \\
\hline
\end{tabular}

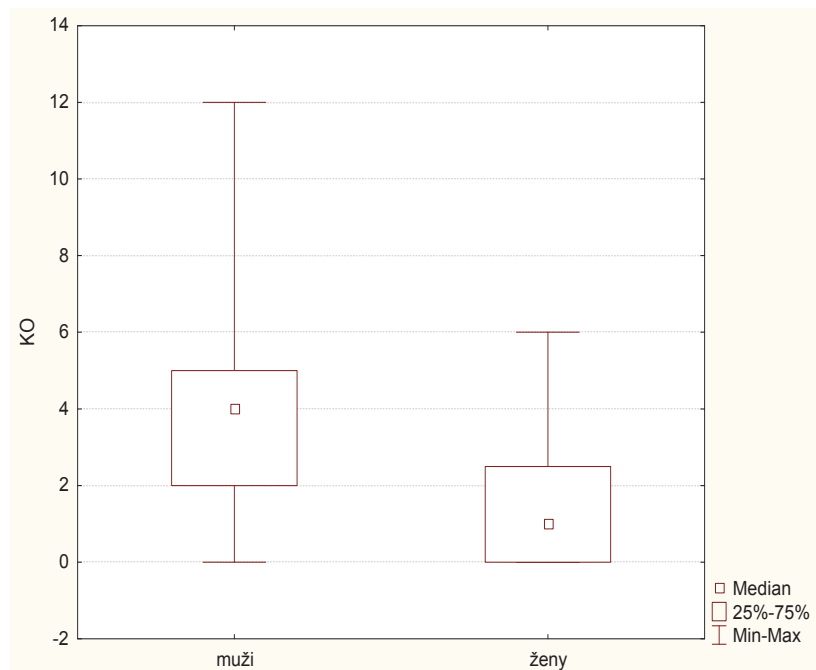

Chart 1. Incidence of conjunctivitis among sexes

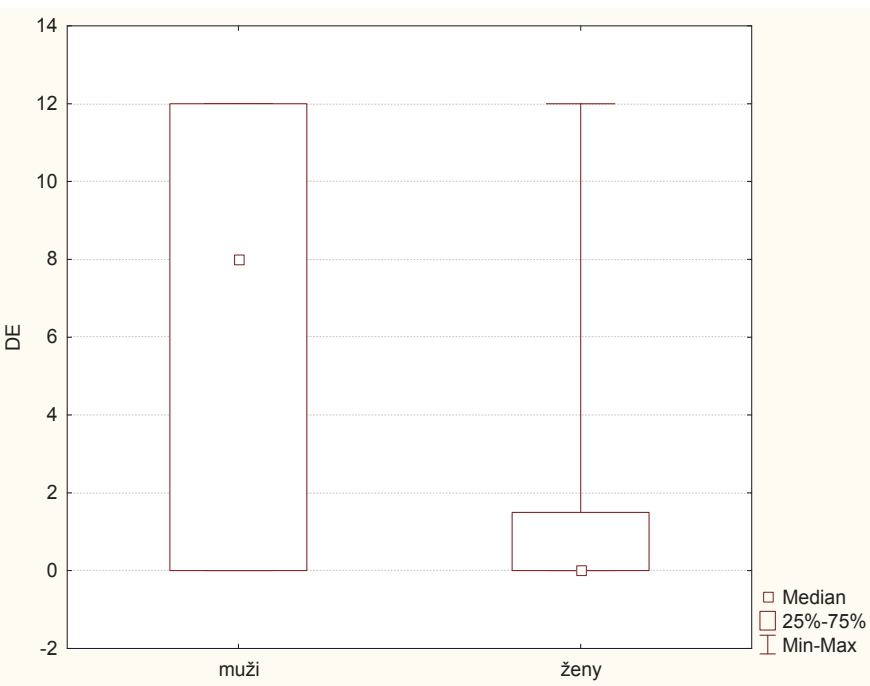

Chart 2. Incidence of decubitus among sexes 


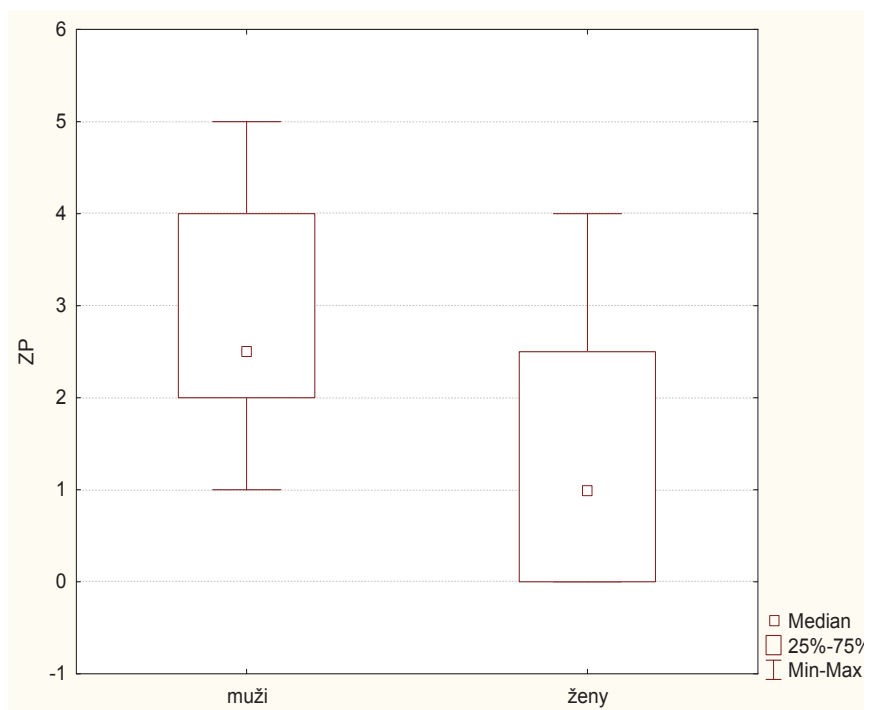

Chart 3. Incidence of sore spots among sexes

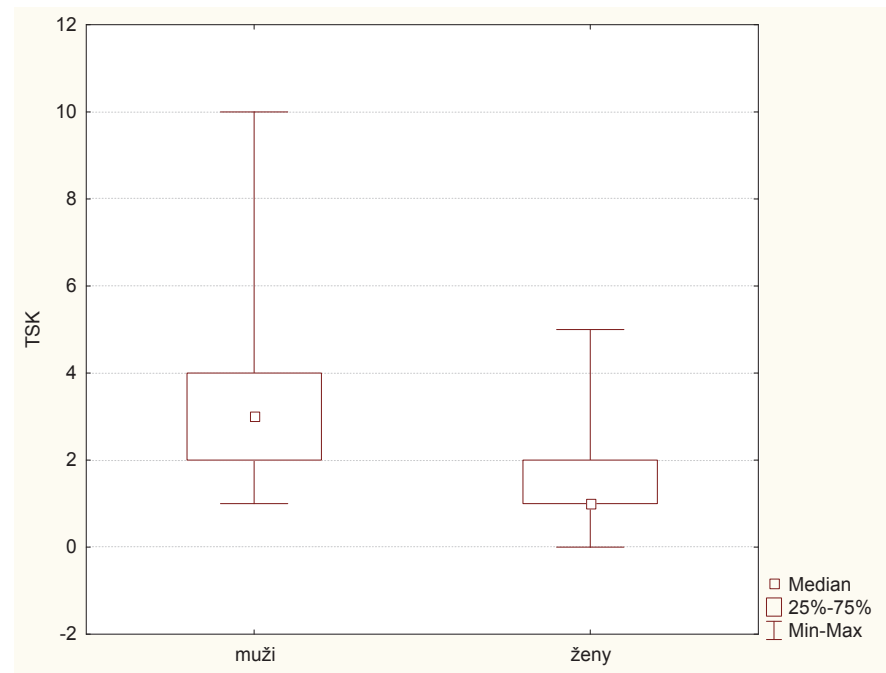

Chart 5. Incidence of inflammation around two-way catheter among sexes

\section{Discussion}

The main objective of the study was to identify the incidence of complications in comatose patients in institutional care. Furthermore, to verify the relationship between the categories by observing and documenting the incidence of individual complications in comatose patients.

Finally, by clarifying interrelationships, the aim was to make it easier to predict the onset of complications in the process of providing intensive nursing care.

Tracheostomy was most frequently reported in comatose patients. However, we do not consider it to be a complication (Table 2). Firment (2009) considers the replacement of lung function by a lung respirator to be the most important activity. This requires the introduction of a two-way catheter - which are interventions required to maintain vital functions in comatose patients. The observed average incidence of decubitus (Table 2) is not assessed as high, taking into account the

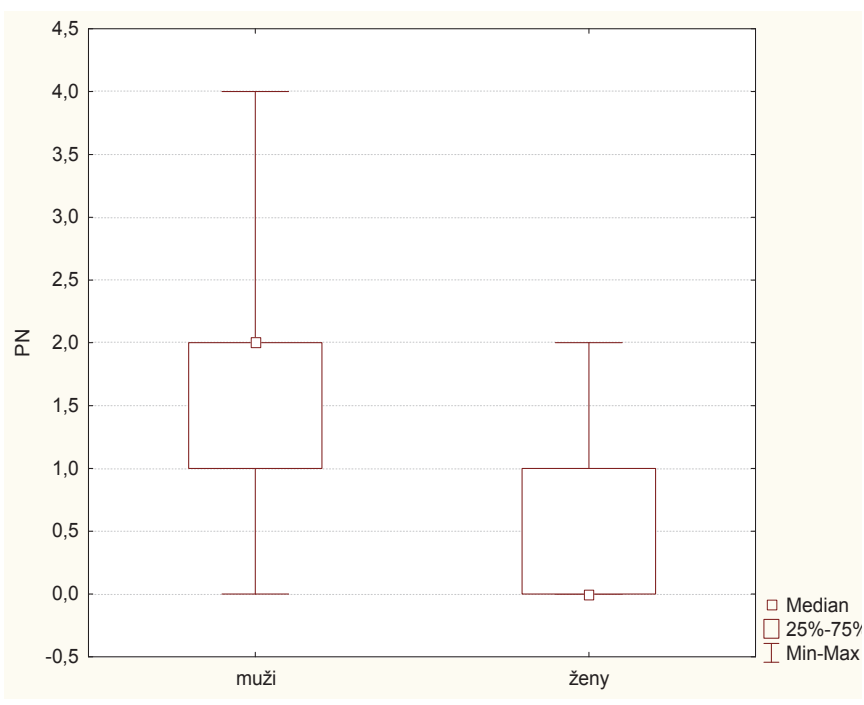

Chart 4. Incidence of pneumonia among sexes

respondents, the severity of the condition and the extremely high care demands. A slightly higher incidence was observed in male respondents (Chart 2 ).

Macková (2013) reports that decubitus is a serious complication for the patient. Also research by Dincer et al. (2018) was focused on the occurrence of decubitus as a complication in palatable patients. The authors reported a pressure ulcer in all 154 patients surveyed during hospitalization and 94 (61\%) on release. The study's authors consider the presence of chronic diseases and immobility as the most significant negative factor for the occurrence of decubitus.

Preventing the formation of decubitus or their treatment is very demanding. It places high demands on nursing care. A less frequent complication observed in comatose patients was the occurrence of intertrigo with higher incidence in male patients (Table 2, Chart 3). According to Krajčík and Bajanová (2012), intertrigo is often a complication of diaper incontinence. Diaper bladder incontinence and stool incontinence increase humidity primarily in areas of the lower back and flank. Humidity allows friction, which causes flush and intertrigo. There are problems of constipation and diarrhea when emptying the colon. These problems may alternate (Miertová et al., 2015). Complications with emptying were also observed in our sample (Table 2). Sabolčáková (2013) stresses that long-term stagnation of stool in the intestine increases the risk of passing intestinal bacteria into the urinary tract. The results of our research also show the significance of constipation or diarrhea in relation to patients' BMI (Table 3 ).

In compliance with doctor's instructions, nutrition was administered using bolus, intermittent or continuous technique to comatose patients of the sample. Enteral feeding was done through PEG (Percutaneous Endoscopic Gastrostomy). As complications of the nutrition, vomiting, inflammation around PEG, as well as inflammation around TSK, which might have been caused by vomiting, were reported. The possibility of the same complications is also reported by Miertová et al. (2015). Other complications in patients of the sample were inflammation of the oral cavity (stomatitis) and inflammation of the conjunctiva of the eye (conjunctivitis) - Table 2. The incidence of conjunctivitis was significantly higher in male respondents (Table 3 , Chart 1 ). We rate it as low. Kubina and Tanuskova (2015) define conjunctivitis as inflammation 
of the conjunctiva that are reddened with the presence of pus. In comatose patients, conjunctivitis is also associated with air conditioning, which is an essential part of the equipment of comatose intensive care units. In critically ill patients, ocular surface disorders often occur, especially when they are sedentary and immobile, according to experts (Imanaka et al., 1997; Sorce et al., 2009). Corneal and conjunctival abnormalities occur in connection with neurological diseases, coma, infection and mechanical ventilation. The authors also highlight the connection between such a condition and the inability to close their eyes. According to Imanaka et al. (1997), an ocular surface defect was found in 28 of 143 patients (20\%) whose stay at ICU exceeded 7 days. The incidence increased with continuous sedation (35\% vs. 15\%) and with continuous neuromuscular blockade.

Furthermore, Sabolcakova (2013) reports that stomatitis occurs more often in patients with artificial lung ventilation or in unconscious patients than in non-ventilated patients. One of the most important options to prevent this complication is oral hygiene. It is important not only from a psychological point of view but also plays an important role in preventing further complications, for example, the occurrence of ventilator pneumonia. The overall prognosis of the patient is affected by the prevention of this serious complication. Snyders et al. (2011) emphasize the provision of antibacterial protection of the oral cavity to prevent the development of pneumonia in critically ill ventilated patients. The most effective, according to the authors, are the preparations containing chlorhexidine at $2 \%$ concentrations.

According to Koenig and Truwita (2006), pneumonia is more common in patients on artificial lung ventilation (ALV) where airways are not protected. Simple and effective preventive measures, according to the authors, could include hand hygiene, head lift, oral (not nasal) cannulation, minimization of sedation, introduction of ALV cutoff reports and reasonable use of antibiotics. Increased demands are placed on sterility and airway hygiene (suction). According to Lančaričová and Frantová (2014), the most appropriate systems are closed, which are largely used in the departments of anaesthesia and intensive care. They also play an important role in the prevention of nosocomial infections - and nosocomial pneumonia. ALV increases the incidence of nosocomial pneumonia 3-10 times. The occurrence of pneumonia in comatose patients on artificial lung ventilation was also investigated by Lascarrou et al. (2017). Of the 250 patients observed, 98 (39.2\%) had aspiration syndrome - 92 of these before interruption of pulmonary ventilation. The results of our study confirmed a significantly higher incidence of pneumonia in male patients (Table 2, Chart 4).

Another observed and reported complication was the incidence of urinary tract infections (Table 2). According to Šefč́lk et al. (2000), urinary tract infections are almost always associated with a used urinary catheter. More often, due to shorter urethra, bacteriuria occurs in women (Lančaričová and Frantová, 2014). According to the author, urinary infections account for up to $40 \%$ of the total incidence of nosocomial infections. Their occurrence is affected by catheterisation, duration, type, method of introduction, type of drainage system, absence of ATB and quality of catheter material. According to
Langšádl (2013), it has been proven that $25 \%$ of the catheterised patients develop bacteriuria within 7 days of catheter introduction. The risk of developing bacteriuria increases by $5 \%$ every day from the introduction of the urinary catheter. Long-term catheterisation causes not only infectious complications, but also non-bacterial inflammation of the urethra, mechanical damage, or even occasional bladder bleeding a complication that was observed in the minimum number of our patients (Table 2). The last complication observed was thrombophlebitis. It may be induced in patients by long-term introduction of PVK (peripheral venous catheter) - Table 2.

By identifying the incidence of complications in a selected group of comatose patients and verifying relationships between the variables specified, the study objectives were met.

Based on the results of the research conducted, we recommend to:

- Regularly monitor and evaluate complications arising in comatose patients. The results of the findings should be used in the effective prevention and constant improvement of the care provided.

- Conduct specialized seminars focused on the possible causes of complications, factors influencing their course and treatment, prevention and improvement of nursing interventions in the already started complications.

- In nursing care provided to comatose patients, maintain standards ensuring continuous improvement in the quality of care provided.

- Increase the practical skills of healthcare professionals by practicing model situations of urgent states that can occur in comatose patients as a consequence of complications that arise.

- Focus on each patient as a unique and individual being with all the bio-psycho-social and spiritual needs and to adapt the provided comprehensive nursing care accordingly.

\section{Conclusions}

The study results show that the reported categories of complications are related to the severity of the comatose condition and correspond to the categories of complications described in the available literature for the same type of patients. Their frequency is low in the sample. An important indicator of the quality of care provided is also the fact that there was no statistical dependence of the incidence of complications - neither on the age nor duration of the comatose state. There was a correlation between the incidence of some complications and respondents' sex and their BMI.

In the care of comatose patients, regular monitoring and evaluation of complications is necessary in order to constantly improve the care provided and eliminate their incidence.

\section{Ethical aspects and conflict of interest}

The study has no conflict of interest. All ethical aspects of research have been respected in its processing. Both the research and interpretation of the results strictly complied with the protection of respondents' personal data. 


\section{Výskyt komplikácií u komatóznych pacientov}

\section{Súhrn}

Úvod: Kóma je t'ažký stav, z ktorého sa pacient nemusí prebrat' celé týždne, mesiace či roky.

Dizajn: Prospektívna kvalitatívna štúdia realizovaná na základe štruktúrovaného pozorovania.

Ciele: Hlavným ciel'om výskumu bolo zmapovat výskyt komplikácií u komatóznych pacientov.

Súbor: Do výskumného súboru bolo celkovo zaradených 22 respondentov v komatóznom stave s priemerným vekom 54,05 rokov, priemerná dížka trvania kómy 3,73 rokov.

Metódy: Na realizáciu výskumu bola použitá metóda štruktúrovaného pozorovania. Použité bolo intervalové kódovanie vopred stanovených kategórií komplikácií, s intervalom každých 30 dní v priebehu jedného roka.

Výsledky: Bola dokázaná užšia súvislost' medzi pohlavím respondentov a výskytom komplikácií $(p=0,05)$; konjuktivitída $(p=$ $-0,46)$; zápal okolia tracheostomickej kanyly $(p=-0,57)$; pneumónie $(p=-0,53)$; intertriga $(p=-0,44)$ a dekubitov $(p=-0,48)$. V celom súbore bola dokázaná štatistická súvislost́ medzi BMI respondentov a výskytom hnačiek $(p=-0,55)$ a BMI a zápchou $(p=-0,78)$. Signifikancia nebola dokázaná medzi výskytom komplikácií a vekom respondentov ani v súvislosti s dížkou trvania komatózneho stavu.

Záver: Výsledky výskumu preukázali nezávislost' výskytu sledovaných komplikácií v súbore komatóznych pacientov od ich veku ani od dížky trvania komatózneho stavu. Bola dokázaná užšia súvislost' medzi pohlavím respondentov a výskytom niektorých komplikácií. Identifikácia komplikácií tohto stavu a špecifík vel'mi náročnej ošetrovatel'skej starostlivosti môže byt' prínosná v rámci poskytovania kvalitnej ošetrovatel'skej starostlivosti o komatóznych pacientov.

Kl'účové slová: komatózny pacient; komatózny stav; komplikácie; ošetrovatel'ská starostlivost'

\section{References}

1. Álvarez-Lerma F, Palomar-Martínez M, Sánchez-García M, Martínez-Alonso M, Álvarez-Rodríguez J, Lorente L (2018). Prevention of ventilator-associated pneumonia: The multimodal approach of the spanish icu "pneumonia zero" program. Crit Care Med 46(2): 181-188. DOI: 10.1097/ CCM.0000000000002736.

2. Bender A, Jox RJ, Grill E, Straube A, Lulé D (2015). Persistent vegetative state and minimally conscious state: a systematic review and meta-analysis of diagnostic procedures. Dtsch Arztebl Int 112(14): 235-242. DOI: 10.3238/arztebl.2015.0235.

3. Bonsignore LT, Macrì S, Orsi P, Chiarotti F, Alleva E (2014). Coma and vegetative states: state of the art and proposal of a novel approach combining existing coma scales. Ann 1st Super Sanita 50(3): 241-248. DOI: 10.4415/ANN_14_03_07.

4. Burns KE, McLaren A (2008). A critical review of thromboembolic complications associated with central venous catheters. Can J Anesth 55(8): 532-541. DOI: 10.1007/ BF03016674.

5. Chlan LL, Heiderscheit A, Skaar DJ, Neidecker MV (2018) Economic evaluation of a patient-directed music intervention for ICU patients receiving mechanical ventilatory support critical care medicine 46(9): 1430-1435. DOI: 10.1097/ CCM.0000000000003199.

6. Dincer M, Doger C, Sen Tas S, Karakaya D (2018). An analysis of patients in palliative care with pressure injuries. Niger J Clin Pract 21(4): 484-491. DOI: 10.4103/njcp.njcp_51_17.

7. Doležil D, Carbolová K (2007). Vegetativní stav (Apalický syndrom). Neurol pro Praxi 1: 27-31.

8. Drábková J (2001). Mozek - Alfa a omega života. Zdravotnické noviny. 2001-6-7. [online] [cit. 2016-03-02]. Available from: http://zdravi.euro.cz/clanek/mozek-alfa-a-omega-zivota

9. Estraneo A, Loreto V, Masotta Psy O, Pascarella A, Trojano L (2018). Do medical complications impact long-term outcomes in prolonged disorders of consciousness? Arch Phys Med Rehabil 99(12): 2523-2531. DOI: 10.1016/j.apmr.2018.04.024.

10. Firment J (2009). Aj pacient ktorý sa preberie z kómy môže žit' bez následkov. Korzár. [online] [cit. 2016-06-23]. Available from: https://kosice.korzar.sme.sk/c/4405975/aj-pacientktory-sa-preberie-z-komy-moze-zit-bez-nasledkov-tvrdiprednosta-kliniky-aim-vo-fnlp-mudr-jozef-firment.html

11. Friedlová K (2008). Bazálna stimulácia v ošetrovatel'ské pěči. Skriptum. Frýdek-Místek: Institut bazálni stimulace.

12. Haškovcová H (2007). Thanatologie: Náuka o umíraní a smrti. Praha: Galén.
13. Imanaka $\mathrm{H}$, Taenaka N, Nakamura J, Aoyama K, Hosotani H (1997). Ocular surface disorders in the critically ill. Anesth Analg 85(2): 343-346.

14. Koenig SM, Truwit JD (2006). Ventilator-associated pneumonia: diagnosis, treatment, and prevention. Clin Microbiol Rev 19(4): 637-657. DOI: 10.1128/CMR.00051-05.

15. Krajčík Š, Bajanová E (2012). Dekubity prevencia a liečba v praxi. Bratislava: Herba.

16. Kubina M, Tanušková D (2015). Mykoplazmová mukozitída a konjunktivitída. Pediatr Prax 16(6): 261-262.

17. Lančaričová $D$, Frantová $M$ (2014). Uzatvorené systémy vyšší štandard ošetrovania. Sestra 13(1-2): 32-34.

18. Langšádl L (2013). Močové infekcie spojené $s$ dlhodobým cievkovaním. Sestra 7(1-2): 27-28.

19. Lascarrou JB, Lissonde F, Le Thuaut A, Bachoumas K, Colin G, Henry Lagarrigue M, et al. (2017). Antibiotic therapy in comatose mechanically ventilated patients following aspiration: differentiating pneumonia from pneumonitis. Crit Care Med 45(8): 1268-1275. DOI: 10.1097/CCM.0000000000002525.

20. Macková A (2013). Monitoring dekubitov. Sestra 12(1-2): 15.

21. Miertová M, Kurča E, Tomagová M, et al. (2015). Ošetrovatel'stvo v neurológii. [online] [cit. 2016-07-09]. Available from: http://osevneu.jfmed.uniba.sk/

22. Opavská V (2001). Pohled sestry na apalický syndrom. Pediatr pro Praxi 4: 195-197.

23. Puggina AC, Paes da Silva MJ, Schnakers C, Laureys S (2012). Nursing care of patients with disorders of consciousness. J Neurosci Nurs 44(5): 260-270. DOI: 10.1097/ JNN.0b013e3182666407.

24. Sabolčáková T (2013). Špecifiká enterálnej výživy v intenzívnej medicíe. Sestra 12(3-4): 42-43.

25. Ševčík P, Černý V, Vítovec J, et al. (2000). Intenzivní medicína. Praha: Galén.

26. Škutchanová A, Minárik M (2014). Súčasný pohl'ad na chronické poruchy vedomia. Anestéziol Intenzívna Med 3(2): 50-53.

27. Snyders O, Khondowe O, Bel J (2011). Oral chlorhexidine in the prevention of ventilator-associated pneumonia in critically ill adults in the ICU: A systematic review. SAJCC Care 27(2): $48-56$.

28. Sorce LR, Hamilton SM, Gauvreau K, Mets MB, Hunter DG, Rahmani B (2009). Preventing corneal abrasions in critically ill children receiving neuromuscular blockade: a randomized, controlled trial. Pediatr Crit Care Med 10(2): 171-175. DOI: 10.1097/PCC.0b013e3181956ccf.

29. Stevens RD, Bhardwaj A (2006). Approach to the comatose patient. Crit Care Med 34(1): 31-41. DOI: 10.1097/01. CCM.0000194534.42661.9F. 